\title{
The Imagination of Criminals in Victorian London in Strange Case of Dr. Jekyll and Mr. Hyde
}

\author{
WONG HIU WAI
}

\begin{abstract}
In this article I write about the split of London described in Strange Case of Dr. Jekyll and Mr. Hyde. Dr. Jekyll, decent and belonging to the middle class, fails to resist the transformation into Mr. Hyde, gross and belonging to the lower class. It represents the fear of the West Enders, who thought that the East Enders were uncivilized and threatening. In order to rationalize their fear, the West Enders imagined the East Enders as criminals, which corresponds to Edward Said's discussion of Orientalism. In Orientalism, Said discusses how the West represents the Orient as the Other, and produces the category of the Orient grounded on a geographical framework of thinking. In much the same way, the story of Jekyll and Hyde demonstrates a narrative construction of the lower class living in the East End London as criminals. The influence of Cesare Lombroso's theory of criminology present in the story serves as important evidence of the West Enders' imagination. In Criminal Man (1876), Lombroso investigates the atavistic criminal, which illustrates the middle-class imagination of the body of the East Enders. Establishing the notion of atavism, Lombroso belittles the lower class by criticizing them as the demonstration of "regression to an earlier stage of evolution." Examining the details of the geographical demarcation portrayed in the story, this paper hopes to elucidate the cultural imagination of criminals in Victorian London.
\end{abstract}

Keywords: criminals; Cesare Lombroso; East London; Edward Said; Robert Louis Stevenson; Jekyll and Hyde

\section{Introduction}

Discussing how the West represents the Orient as the Other, Edward W. Said's Orientalism (1978) sheds light on the cultural construction of the class of criminals. One has to look at Said's analysis of Orientalism: "Without examining Orientalism as a discourse one cannot possibly understand the enormously systematic discipline by which European culture was able to manage - and even produce - the Orient, politically, sociologically, militarily, ideologically, scientifically, and imaginatively" (Said 1979: 3). Most 
WONG

importantly, the production of the category of the Orient is grounded in a geographical framework of thinking. Said explains that "the geographic boundaries accompany the social, ethnic, and cultural ones in expected ways" (ibid. 54). Hence, geographical demarcation is not merely a field of science, which is supposedly objective and factual, but is an imagination, which is subjective and ideological. With the territorial "sense of confrontation felt by Westerners dealing with the East," the Occident has to establish "the boundary notion of East and West," namely "a willed imaginative and geographic division made between East and West” (ibid. 201). Therefore, such a geographical entity as "Asia acquired a precise intellectual and historical dimension with which to buttress the myths of its geographical distance and vastness" (ibid. 77). As a class which attains economic supremacy by dominating capital and the means of production, the middle class controls the production of cultural discourse. Therefore, there is narrative construction of various types of social classes, including the class of criminals, the colored, and the poor. It is thus not hard to find that the class of criminals, living in slums and dark street corners, is a geographical imagination originating from those who are richer and superior.

In Robert Louis Stevenson's Strange Case of Dr. Jekyll and Mr. Hyde, the protagonist Dr. Jekyll, who is sometimes Mr. Hyde, catches the reader's attention by displaying duality. Jekyll's change of identity is intriguing, since after drinking a potion he does not turn himself into a higher, admirable, modern hero as in stories of superman or iron man, but a lower, detestable, animalistic ape man. As a Gothic novel that probes into the SF theme of exploring the boundary of scientific experiment which ignites everyone's curiosity, the story presents a topic that is important in the Gothic tradition, the Gothic doppelganger. From Matthew Lewis's The Monk (1796), Mary Shelley's Frankenstein (1818), Oscar Wilde's The Picture of Dorian Gray (1891), to Bram Stoker's Dracula (1897), the character of doppelganger, with one person dividing into two identities, addresses the fear and anxiety of the British people in the nineteenth century when changes were brought by industrialism and London was split into the West End and the East End.

Duplicity, animalistic appearance, and the split of London - these are elements that surround Jekyll and Hyde, and the interrelationship between these three is worth a discussion. Finding that London was divided into two cities at that time, I will look into how the opposition between Jekyll and Hyde may represent such geographical division. Importantly, the animalistic traits of Hyde function as elements that belittle those living in East End London. To analyze the relationship between atavism and the East Enders, I will discuss Cesare Lombroso's Criminal Man, a pseudo-scientific theory that equates 
The Imagination of Criminals in Victorian London

criminals with the poor. Situating Hyde in the Victorian background, this paper attempts to excavate the significance of his animalistic look and behavior.

\section{Double London}

In the Victorian era, the character of doppelganger, meaning double, was tied to the fact that Londoners were living a double life when London was split into two cities, the West End and the East End, the cultivated, rich, and vain, in opposition to the primitive, poor, and dirty. What was worse was that the West End often took advantage of the East End. In fact, the prosperity of the posh West End was built upon the hard work of the poor working-class people in the East End to sustain its glory. In London: A Social History, Roy Porter, the scholar who looks into the formation of London since Roman times, describes how poor people living in the East End were doomed for London's "share of dirty trades":

Scattered through the East End and in the poorer Surrey suburbs were boneboilers, grease-makers, paint-makers and the dye works of Southwark ('an odious stinking business') ... Sugar-houses crystallized in Ratcliff and St Katherine's, and starch-works in East Smithfield, Whitechapel and Poplar... (Porter 1994: 142)

Suffused by bad smell and grey dirty air, the East Enders had to carry on the nasty work of industrialism to keep the huge, shiny engine of London running. The East End, serving as the ostracized, inferior area, "has long been the poor suburb of the City of London" (Eade 2000: 123).

In Placing London: From Imperial Capital to Global City, John Eade, the scholar who attempts to discuss the gap between the glorified nation and the deplorable working class of the city, discussed how the division of work practiced under industrialism forced the East Enders to sacrifice their own welfare and contribute to the greater good of the rich in the Victorian era:

The Victorian East End was shaped by the occupational divisions integral to the manufacturing belt, which linked the area to the small craft workshops of Soho and the factories across the River Thames in Southwark...The goods and services produced in, or flowing through, the East End created a large part of London's wealth during the nineteenth century and brought immense riches to the City of London's merchants, bankers, shipowners, and investors. (Eade 2000: 124) 
WONG

The East End "rapidly expanded into a working-class area containing substantial pockets of intense poverty," when "its residents were excluded from the centres of political and social power until the early twentieth century" (ibid. 123). The nineteenth century was the turning era when a sharp discrepancy between the East End and the West End was formed, separating the rude, lower-class people from the elegant, upper-middle-class people.

Soho, the filthy area, haunted the West Enders as threatening. In Capital Offenses: Geographies of Class and Crime in Victorian London, Simon Joyce accounts that after the "outbreak of cholera in the 1850s" (Joyce 2003: 9), Soho became a place "harboring immigrant populations and criminality" (ibid. 10). A "schizophrenic area like Soho" (ibid.) was nothing less than "the perfect cover for a life of crime, as well as a convenient distance from Jekyll's West End surgery" (ibid.). The East End is "a symbol of a nation's dark side, shaped by the divisions of class, ethnicity, race, and gender" (Eade 2000: 124). The rise of the Victorian popular press showed that the East was remarkable for its crime problem. On September 14, 1888, the Star reported: "Neighborhoods go mad like individuals, and, while the West sits discussing the Whitechapel horrors over its wine, the East is seething with impatience, distrust, horror. What a situation!" (What We Think... 1888). The division between the elegant West and the wretched East was clear. Both were stunned by the murders, but those in the West could talk over a glass of wine, while those in the East were severely disturbed.

As a consequence, the East was a place where respectable gentlemen and ladies would not visit. Ackroyd describes:

The potent combination of sexuality and criminality was too tempting to be resisted, and so the East End became generally depicted as the heart of darkness. The phrase itself, 'East End,' was not invented until this decade." (Ackroyd 2012: 13).

As the site of darkness, the term "East End" was constructed by the West in order to imagine and depict the horror of discovering the wicked side of humans.

Due to these circumstances, doubling became a burning topic which represented conflicts that long existed in Victorian society, implicating issues such as class and masculinity. ${ }^{1}$ While Wilde's and Stoker's stories of double life

\footnotetext{
According to Andrew Smith, "that models of masculinity became implicated in this 'horror' (the 'good' bourgeois, the working class 'Jack') received an added emphasis given that accounts of the relationship between West End and East End frequently exploited the language of Empire" (75).
} 
refer to a pair of characters, Dorian Gray and his mirrored self, and Jonathan Harker and Dracula, whose lives are entwined, Stevenson's characters, Jekyll and Hyde, stand out differently as one person in two bodies. Actually, Jekyll and Hyde are similar to London in the Victorian era, which was one city divided into two parts. In Victorian Demons: Medicine, Masculinity, and the Gothic at the Fin-de-Siècle, Andrew Smith points out that the city of London itself, "at a metaphorical level, became personified as a monstrous Gothic being whose double life appeared to be beyond rational control” (Smith 2004: 75).

\section{Hyde is in the East while Jekyll is in the West}

Grounded in the fact that the descriptions of the "split" identity of Dr. Jekyll makes it "the best-known Doppelganger story of them all" (Punter 2014: 2), I will explore Jekyll's doubling by looking into the geographical division of the East End and the West End London. Respectively, Jekyll and Hyde dwell in the west and the east, which explains how London was split into two extremes. ${ }^{2}$

For the West End, in the second chapter, "Search for Mr Hyde," it is emphasized that Jekyll lives in the West End area where wealthy doctors in Victorian London gathered. It is highlighted that Jekyll buys his house from a famous doctor:

The doctor had bought the house from the heirs of a celebrated surgeon; and his own tastes being rather chemical than anatomical, had changed the destination of the block at the bottom of the garden. (Stevenson 1994: 34)

It is a house "which wore a great air of wealth and comfort" (Stevenson 1994: 23), and has "a large, low-roofed, comfortable hall, paved with flags, warmed (after the fashion of a country house) by a bright, open fire, and furnished with costly cabinets of oak" (ibid. 24). Therefore, Utterson cannot help but think of the house as one of the best: "Utterson himself was wont to speak of it as the

2 Enfield and Utterson are used to living on the west side, walking "down a by street in a busy quarter of London" (Stevenson 1994: 10). The descriptions of the westside street are positive and hopeful: "The street was small and what is called quiet, but it drove a thriving trade on the week-days. The inhabitants were all doing well, it seemed, and all emulously hoping to do better still..." (Stevenson 1994: 10). The street on the west contrasts with that on the east: "The street shone out in contrast to its dingy neighbourhood, like a fire in a forest; and with its freshly painted shutters, well-polished brasses, and general cleanliness ad gaiety of note, instantly caught and pleased the eye of the passenger" (Stevenson 1994: 10). 
WONG

pleasantest room in London" (ibid.). When Utterson attempts to visit Jekyll, Poole the butler appears to Utterson as "a well-dressed, elderly servant" (ibid.).

As for Jekyll's friends, Dr Lanyon "had his house and received his crowding patients" on Cavendish Square, which was a "citadel of medicine" (ibid. 18), a wealthy region for doctors in the Victorian age. According to Porter, Cavendish Square "was the nucleus of the Harley-Cavendish estate, another child of a shrewd marriage alliance, between the $2^{\text {nd }}$ Earl of Oxford (hence Oxford street) and Henrietta Cavendish" (Porter 1994: 110). Authors such as Charles Dickens, Nicholas Nickleby, Little Dorrit and Barnaby Rudge have helped made the place known. During the mid-nineteenth century, Cavendish Square was a site for upper-middle class gathering, and thus many physicians chose to establish their consulting rooms there. According to Russ Willey, it has become “London's premier address for private doctors." The name of Cavendish Square "remains synonymous with expensive consultancy, including newer forms of treatment such as cosmetic surgery" (Willey 2007). As for Utterson, he lives on Gaunt street (Stevenson 1994: 22), which again symbolizes the uppermiddle class of the West End. According to Roger Luckhurst, Gaunt Street did not exist at Stevenson's time, but obviously Stevenson borrows a nineteenthcentury literary allusion from William Makepeace Thackeray, who in Vanity Fair describes that Lord Steyne has a town palace in Gaunt Square, besides the Great Gaunt Street. Gaunt Square signifies the upper-middle society, "described as on the way down from its aristocratic heights" (Luckhurst 2006: 186), connected to doctors and banks.

As a consequence, the connection between Jekyll and the upper-middle class is emphasized when Jekyll's social life consisting of dinner parties and hosting charity events are described. He is in the habit of inviting friends who are doctors and lawyers to dinners: "the doctor gave one of his pleasant dinners to some five or six old cronies, all intelligent reputable men, and all judges of good wine" (Stevenson 1994: 26). Moreover, "he had always been known for charities" and "he was now no less distinguished for religion" (ibid. 40). Jekyll is hence described as "a large, well-made, smooth-faced man of fifty" (ibid. 26).

What is hugely astounding is that the reader would assume that Hyde, as the double of Jekyll, should be able to live in Jekyll's house, but instead he lives in the notorious Soho area in the East End. When Utterson approaches Hyde at his doorstep, Hyde "gave a number of a street in Soho" (ibid. 22) to him. As Utterson determines to probe into the life of Hyde by visiting his home, he finds Soho "a district of some city in a nightmare" (ibid. 32). "As the cab crawled from street to street" (ibid.), what Utterson sees clearly shows the lower-class traits of East London: 
The dismal quarter of Soho seen under these changing glimpses, with its muddy ways, and slatternly passengers, and its lamps, which had never been extinguished or had been kindled afresh to combat this mournful reinvasion of darkness... (Stevenson 1994: 31-32)

Terms such as "muddy," "slatternly," and "nightmare" obviously mark Soho as a place that the doctors would not like to visit. The street on which Hyde lives is also "a dingy street," where one finds "a low French eating-house, a shop for the retail of penny numbers and two-penny salads, many ragged children huddled in the doorways, and many women of many different nationalities passing out" (Stevenson 1994: 32). With all these in mind, Utterson cannot help but think: "This was the home of Henry Jekyll's favourite; of a man who was heir to a quarter of a million sterling" (ibid.). He feels devastated to find that Hyde, as Jekyll's friend, lives in such an indecent area.

Although the story does not portray the West End and the East End as a realistic fiction, Stevenson apparently employs the duality of Jekyll and Hyde to emblematize the split status of London. As Jekyll and Hyde stand for the West End and the East End, the Victorian reader could grasp the contrast between the two halves of the city more precisely. In one word, the novel's depictions of the inferiority of Hyde and Soho are eminent. That is why Stevenson has it arranged that after Jekyll drinks the potion and turns into Hyde, he leaves the West End and moves to the East End.

One observes that "London's transition from an imperial capital to a global city has entailed the realignment of boundaries," namely banishing all the poor people to the East End (Eade 2000: 126). The East End earns its "reputation for poverty and widespread population" (ibid. 124). To keep the West End glorified and polished, people living in the East End have to get along with "intense poverty, violence, and the contemporary settlement of aliens (East European Jews)" (ibid.). To the West Enders, the East Enders were primitive people living in London, a race of the Other that could never fit in.

\section{Lombroso's Imagination of The East Enders As the Black in London}

Published in 1876, Criminal Man, Cesare Lombroso's repertoire which investigates the atavistic criminal, inspired Stevenson's portrayal of Mr Hyde. Arata writes that “in Edward Hyde, Stevenson's first readers could easily discern the lineaments of Lombroso's atavistic criminal" (Arata 1996: 33). As a scientist of biological determinism, Lombroso explored atavism present in criminals and 
WONG

his work influenced criminology in Europe. In a chapter named "Crime and Inferior Organisms," Lombroso asks the question "who is unfamiliar with the fascinating descriptions of insectivorous plants by Darwin?" (Lombroso 2006: 167) Grounded in Darwinism, Lombroso points out the sameness between criminals and plants and animals. He writes: "The comparison of human crimes to those of lower organism becomes much clearer when we consider the zoological world" (ibid. 168).

Most importantly, Lombroso's criminological theory is a middle-class imagination of the body of the East Enders. Establishing the notion of atavism, Lombroso belittles the lower class by criticizing them as the demonstration of "regression to an earlier stage of evolution" (Gibson \& Rafter 2006: 39). There are "signs of atavism" which "mark the body and mind of the criminal" (ibid.). Lombroso states:

These facts clearly prove that the most horrendous and inhuman crimes have $\mathrm{a}[\mathrm{n}]$... atavistic origin in those animalistic instincts that, although smoothed over by education, the family, and fear of punishment, resurface instantly under given circumstances. (Lombroso 2006: 91)

When encountering "illness, the weather," and "bad examples" (Lombroso 91), those who are born with atavistic brains may develop a criminal tendency that is long hidden. Mary Gibson and Nicole Hahn Rafter account Lombroso's "born criminal" as "a dangerous individual marked by what he called "anomalies"- physical and psychological abnormalities," which "resembled the traits of primitive peoples, animals, and even plants” (Gibson \& Rafter 2006: 1).

One of the most important creeds of Criminal Man is to identify the abnormal biological traits of the lower-class people and prove that they are criminals. Lombroso lists some concrete physical traits of criminals, including "frequent occurrence of the medium occipital fossetta, overdevelopment of the jaw and cheekbones, prognathism, oblique and large eye sockets, dark skin, thick and curly head hair, large or protuberant ears, long arms, similarity between sexes, left-handedness"(Lombroso 2006: 222).

Corresponding to Lombroso's descriptions of the atavistic traits of the lower class, Jekyll deforms from "a tall fine build of a man” into Hyde, who looks "more of a dwarf" (Stevenson 1994: 52). As an East Ender, Hyde is apparently shortened, which makes him a retrogressed version of the uppermiddle-class doctor. He finds Jekyll's clothes "enormously too large for him in every measurement - the trousers hanging on his legs and rolled up to keep 
The Imagination of Criminals in Victorian London

them from the ground, the waist of the coat below his haunches, and the collar sprawling wide upon his shoulders" (ibid. 65). A tiny man in large clothes, Hyde becomes "laughable," "ludicrous," (ibid.) "abnormal and misbegotten" (ibid.), and "evil was written broadly and plainly on the face" (ibid. 73).

Besides displaying "ape-like tricks" (ibid. 87) alongside with "his ape-like spite" (ibid. 88), Hyde shows an ineffable, inhuman appearance, one that can barely be conveyed by language:

He is not easy to describe. There is something wrong with his appearance; something displeasing, something downright detestable. I never saw a man I so disliked, and yet I scarce know why. He must be deformed somewhere; he gives a strong feeling of deformity, although I couldn't specify the point. He's an extraordinary-looking man, and yet I really can name nothing out of the way. (Stevenson 1994: 15)

Mumbling that "no, sir...I can't describe him” (Stevenson 1994: 15), Enfield emphasizes that Hyde's look is "extraordinary" and cannot be conveyed by the usual descriptions of man.

Using "it" to denote Hyde, hence, it is explained that Hyde looks like a creature that is lesser than a man:

It wasn't like a man; it was like some damned Juggernaut...He was...so ugly that it brought out the sweat on me like running.... and there was the man in the middle, with a kind of black sneering coolness... but carrying it off, sir, really like Satan. (Stevenson 1994: 12)

A "juggernaut" refers to a huge lorry which carries goods, while Satan obviously the force of evilness. "Evil" "had left on that body an imprint of deformity and decay" (Stevenson 1994: 73). Both comparisons suggest negative characters that are not "like a man" and worse than a man.

Most importantly, Hyde's atavism is not only revealed by his ape-like appearance, but is also further illustrated by his primitive behavior. Before he turns into Hyde, Jekyll is a doctor who is "dignified, kind, and well-regarded pillar of society" (Schellinger 2014: 1288) who never causes harm to others. However, after drinking the potion, Hyde becomes a degenerated ape man who fails to conform to the civilized West London and "snarled loud into a savage laugh" (Stevenson 1994: 23). As such, he cannot help but commit crime one after another. He commits the first crime by attacking a little girl. Enfield recounts what he witnesses: 
WONG

\begin{abstract}
All at once, I saw two figures: one a little man who was stumping along eastward at a good walk, and the other a girl of maybe eight or ten who was running as hard as she was able down a cross-street. Well, sir, the two ran into one another naturally enough at the corner; and then came the horrible part of the thing; for the man trampled calmly over the child's body and left her screaming on the ground. (Stevenson 1994: 11-12)
\end{abstract}

After the outrageous onslaught on a child, Hyde is caught by Enfield and other witnesses. Enfield and the girl's family "had taken a loathing to" Hyde "at first sight" (Stevenson 1994: 12). The look of Hyde is so disgusting that everyone "turned sick and white" (ibid.).

The other felony that Hyde commits is the murder of an aged gentleman of a "high position" (ibid. 29). This time the process of attack is described in more detail to emphasize Hyde's primitiveness:

The old gentleman took a step back, with the air of one very much surprised and a trifle hurt; and at that Mr Hyde broke out of all bounds, and clubbed him to the earth. And next moment, with ape-like fury, he was trampling his victim under foot, and hailing down a storm of blows, under which the bones were audibly shattered and the body jumped upon the roadway. (Stevenson 1994: 30)

Hyde "broke out in a great flame of anger" (Stevenson 1994: 30) and is as aggressive as an animal unleashed. Without any motive, such as the need for money or revenge, Hyde merely attacks pedestrians on the road out of animal instinct. His emotions of anger are purely intense and "ape-like."

\title{
Conclusion: Jekyll and Hyde as the Example of the "Process of Transference"
}

According to Paul Spicker, who discusses how the poor are blamed in The Idea of Poverty, "the moral condemnation of the poor" "turns poor people into something different from ourselves, and puts them at a distance" (Spicker 2007: 101). Charles Murray, in "The Emerging British Underclass," defines the underclass as those affiliated with "drugs, crime, illegitimacy, homelessness, drop-out from the job market, drop-out from school, casual violence" (Murray 1996: 25). Grounded in a kind of guilt originating from the unequal distribution of wealth, the middle class purposively produces a new class, the class of criminals, to categorize the poor. With this new class of criminals, the middle class can enjoy the excess of income and social status that comes from the exploitation of the poor. The middle class produces the new class of criminals in order to ensure that the poor deserve the inferior economic 
and social status, since they have worse moral standards and their behaviors endanger society.

Thus, the middle class always imagines the poor as criminals, gross and threatening. In The Unheavenly City, Edward Banfield writes: "The lower class individual lives in a slum and sees little or no reason to complain. He does not care how dirty or dilapidated his housing is either inside or out, nor does he mind the inadequacy of such public facilities as schools, parks and libraries; indeed, where such things exist he destroys them by acts of vandalism if he can" (Banfield 1968: 62). Banfield points out that the middle class assumes that the poor criminals are born into this kind of unfavorable circumstances and enjoy belonging to the lower class.

The mechanism of shifting the inferior traits to the lower class is analyzed by David Taylor in "Beyond the Bounds of Respectable Society: The 'Dangerous Classes' in Victorian and Edwardian England." He puts forth the notion, the "process of transference," to denote the way "the 'under-world' mirrors the 'over-world' in its highly complex structure but in that mirror world the moral order has been subverted and 'good' replaced by 'evil'” (Taylor 2005: 8). Seeing the poor as a group of people living in a mirror world, "all that is seen to be immoral, all that is feared in bourgeois society," is attributed to "the inhabitants of the slums and rookeries" (ibid.). Transfering all the inferior traits to the lower class and coloring them as dangerous and gross, "not only has an 'other' or 'nether' world been constructed but also the superiority of 'respectable' values has been confirmed" (ibid.).

Through this process of transference, the class of criminals is established by words and imagination, which is a notion so widespread that most Victorian middle-class people believed that there were really a kind of population that was different from the common people and were threatening. The East Enders serve as the mirror image of the West Enders, reflecting all their characteristics upside down. Merely looking at the East Enders is an activity of invention. The West Enders build up the other as vicious and dirty, and their original self can stay kind and clean.

With this geographical construction of the other, doctors and lawyers such as Jekyll, Enfield, and Utterson find that they can stay in the upper rank of the West End more safely. Taylor writes: "The construction of the category of threatening 'others', which was to be found in specific geographical areas, gave both a sense of moral superiority and a sense of security" (ibid. 10). Feverishly painting Hyde and other East Enders as vulgar and detestable, the West Enders were comparable to the White people who imagined the Oriental people as uncivilized and in need of salvation. "Those intrepid domestic explorers 
WONG

discovering the East End of London were effectively involved in the same process of discovery definition that Said associates with the West's contact with the Orient" (ibid. 8). Within this process of transference, the poor are painted as dangerous and unstable, characteristics which make them fall into the category of criminals. Believing that the class of criminals are innately evil, the rich free themselves from the guilt of exploiting the poor and blocking the opportunities of getting educated and civilized, and becoming a better person.

It is thus not hard to understand that slums are geographically conceived as a district for a primitive kind of people. In Crime, Protest, Community, and Police in Nineteenth-Century Britain, David Jones points out that the nineteenth century saw "a tendency to locate crime within certain districts" (Jones 2015: 9). The crowded ghetto area was viewed as the hotbed of crime. Alongside with this inclination to geographically discriminate against a group of people living in a certain area, London was said to be a city that was marked by the gathering of atavistic criminals. Social scientists "were convinced that London, ...the home of the sweated trades, casual employment and bad housing, had become the most dangerous city in western Europe" (ibid. 10). "A series of enquiries were made into the environment and population of its slum areas" (ibid.). The nineteenth-century scientific research discovered that criminals belong to a class "with an incomplete family life, depressed in mind and body, holding values at variances with those of respectable society, and transmitting antisocial patterns of behaviour from one generation to the next" (ibid.).

Hence, in the opening address of Henry Austin Bruce, 1st Baron Aberdare, to The National Association for the Promotion of Social Science in 1875, one finds the unreasonable link between the class of the poor and the class of criminals. Bruce said:

Narrow streets, close courts, ill-ventilated and crowded houses generate disease, disease poverty, and poverty but too often produces crime. Evil communication corrupts good manners; and evil associations are inevitable in these resorts of the miserable, the vicious, the drunkard, and the criminal... It is difficult...to prove how large a part of our national crime is due to the bad housing of our poorer classes. (Bruce 1876: 39)

This passage explains how the nineteenth-century middle class was involved in the process of transference, employing imagination to strengthen their superiority and find the reason to look down on the other, the poor, which is represented by Hyde. 
The Imagination of Criminals in Victorian London

\author{
Wong Hiu Wai \\ nicoleanw@yahoo.com.tw \\ Kaohsiung Medical University \\ The Center for Languages and Culture \\ No.100, Shiquan 1st Rd. \\ Sanmin Dist., Kaohsiung City \\ TAIWAN
}

\title{
Bibliography
}

Ackroyd, P. 2012.Introduction. - A. Werner ed., Jack the Ripper and the East End. London: Random House, 7-30.

Arata, S. 1996. The sedulous ape: atavism, professionalism, and Stevenson's Jekyll and Hyde. - Fictions of Loss in the Victorian Fin de Siècle: Identity and Empire. Cambridge: Cambridge University Press, 33-53.

Banfield, E. 1968. The Unheavenly City: The Natural and Future of Our Urban Crisis. New York: Viking Press.

Bruce, H. A. 1876. Opening Address. - C. W. Ryalls, ed., Transactions of The National Association for the Promotion of Social Science: Brighton Meeting, 1875. London: Longmans, Green, and Co, 1-45.

Eade, J. 2000. The East End: The Transformation of Place. - Placing London: From Imperial Capital to Global City. New York: Berghahn Books, 123-136.

Gibson, M.; Rafter, N. H. 2006. Introduction. - C. Lombroso, Criminal Man. Durham: Duke University Press, 1-42.

Jones, D. 2015. Crime, Protest, Community, and Police in Nineteenth-Century Britain. New York: Routledge.

Joyce, S. 2003. Capital Offenses: Geographies of Class and Crime in Victorian London. Charlottesville: University of Virginia Press.

Lombroso, C. 2006. Criminal Man. Transl. by M. Gibson and N. H. Rafter. Durham: Duke University Press.

Luckhurst, R. 2006. Explanatory Notes. - R. Luckhurst, ed.,Strange Case of Dr Jekyll and Mr Hyde and Other Tales. Oxford: Oxford University Press, 184-204.

Murray, C. 1996. The Emerging British Underclass. - Charles Murray and the Underclass: The Developing Debate. London: The IEA Health and Welfare Unit, 23-53.

Porter, R. 1994. Commercial City: 1650-1800. - London: A Social History. Cambridge, MA: Harvard University Press, 131-159.

Punter, D. 2014. The Literature of Terror: A History of Gothic Fictions from 1765 to the Present Day. New York: Routledge.

Said, E. W. 1979. Orientalism. New York: Vintage Books.

Schellinger, P. 2014. The Strange Case of Dr Jekyll and Mr Hyde by Robert Louis Stevenson. - Encyclopedia of the Novel. New York: Routledge, 1288-1289. 
WONG

Smith, A. 2004. The Whitechapel Murders: Journalism, Gothic London, and the Medical Gaze. - Victorian Demons: Medicine, Masculinity, and the Gothic at the Finde-Siècle. Manchester: Manchester University Press, 67-94.

Spicker, P. 2007. The Idea of Poverty. Bristol: Policy Press.

Stevenson, R. L. 1994. The Strange Case of Dr. Jekyll and Mr. Hyde. London: Penguin Books.

Taylor, D. 2005. Beyond the Bounds of Respectable Society: The "Dangerous Classes" in Victorian and Edwardian England. - J. Rowbotham, K. Stevenson, eds., Criminal Conversations: Victorian Crimes, Social Panic, and Moral Outrage. Ohio: Ohio State University Press, 1-20.

What We Think. 1888. - The Star, 14.09.

Willey, R. 2017. Hidden London. - http://hidden-london.com/gazetteer/harley-street/ (03.03.2019). 